\title{
Modeling Global Warming Potential, Variable Costs, and Water Use of Young Plant Production System Components Using Life Cycle Assessment
}

\author{
Dewayne L. Ingram ${ }^{1,4}$ \\ Department of Horticulture, University of Kentucky, N-318 Ag Science \\ North, Lexington, KY 40546-0091
}

Charles R. Hall ${ }^{2}$

International Floriculture, Department of Horticultural Sciences, Texas A\&M University, 2133 TAMU, College Station, TX 77843-2133

\author{
Joshua Knight $\mathbf{t}^{3}$ \\ Department of Horticulture, University of Kentucky, $\mathrm{N}-318 \mathrm{Ag}$ Science \\ North, Lexington, KY 40546-0091
}

Additional index words. floriculture crops, greenhouse production, propagation

\begin{abstract}
The components for two production systems for young foliage plants in 72-count propagation trays were analyzed using life cycle assessment (LCA) procedures. The systems differed by greenhouse type, bench size and arrangement, rainwater capture, and irrigation/fertilization methods. System A was modeled as a gutter-connected, rounded-arch greenhouse without a ridge vent and covered with double-layer polyethylene, and the plants were fertigated through sprinklers on stationary benches. System B was modeled as a more modern gutter-connected, Dutch-style greenhouse using natural ventilation, and moveable, ebb-flood production tables. Inventories of input products, equipment use, and labor were generated from the protocols for those scenarios and a LCA was conducted to determine impacts on the respective greenhouse gas emissions (GHG) and the subsequent carbon footprint (CF) of foliage plants at the farm gate. CF is expressed in global warming potential for a 100-year period (GWP) in units of kilograms of carbon dioxide equivalents $\left(\mathrm{kg} \mathrm{CO}_{2} \mathrm{e}\right)$. The GWP of the 72-count trays were calculated as 4.225 and $2.276 \mathrm{~kg} \mathrm{CO} \mathrm{CO}_{2} \mathrm{e}$ with variable costs of $\$ 25.251$ and $\$ \mathbf{2 4 . 8 5 7}$ for trays of foliage plants grown using Systems A and B, respectively. The GWP of most inputs and processes were similar between the two systems. Generally, the more modern greenhouse in System B was more efficient in terms of space use for production, heating and cooling, fertilization, and water use. While overhead costs were not measured, these differences in efficiency would also help to offset any increases in overhead costs per square foot associated with higher-cost, more modern greenhouse facilities. Thus, growers should consider the gains in efficiency and their influences on CF, variable costs (and overhead costs) when making future decisions regarding investment in greenhouse structures.
\end{abstract}

Greenhouse production of floricultural and foliage plants in the United States is in the mature stage of its industry life cycle and increasingly hypercompetitive, with growers experiencing low profit margins despite having

\footnotetext{
Received for publication 16 June 2017. Accepted for publication 10 Aug. 2017.

This material is based on work that is supported by the National Institute of Food and Agriculture, U.S. Department of Agriculture, Specialty Crop Research Initiative, under award number 2014-51181-22372.

${ }^{1}$ Professor.

${ }^{2}$ Professor and Ellison Chair.

${ }^{3}$ Extension Associate.

${ }^{4}$ Corresponding author. E-mail: dingram@uky. edu.
}

to incur substantial capital expenditures (Hall, 2010). In such a setting, it is desirable to maximize efficiency, yet simultaneously reduce costs. Growers can often accomplish this by introducing lean manufacturing techniques into their respective value chains. Recent literature points to the interconnectedness of efficient input use, cost savings, enhanced product quality, and the sustainable nature of production or manufacturing practices (Boston Consulting Group, 2009). In other words, sustainable practices are now viewed as profitable strategic imperatives rather than mere environmental regulatory adherence (Rankin et al., 2011).

For green industry firms, sustainable production means using best management practices that enhance plant quality and simultaneously reduce environmental impacts (Southern Nursery Association, 2013). Evaluating the triple-bottom-line aspects of their business (people, planet, and profits) can also help to differentiate their firms in the marketplace (Hall, 2010). Life cycle assessment is a tool that has been used to evaluate the environmental portion of the triplebottom-line of products from cradle to grave or defined subsets of their life cycle.

Greenhouse gas emissions and the subsequent CF have been reported for nursery crop production systems in the U.S. (Hall and Ingram, 2014, 2015; Ingram, 2012, 2013; Ingram and Hall, 2013, 2014a, 2014b, 2015a, 2015b; Ingram et al., 2016; Kendall and McPherson, 2012). CF is expressed in GWP in units of kilograms of carbon dioxide equivalents $\left(\mathrm{kg} \mathrm{CO}_{2} \mathrm{e}\right)$. In addition to analyzing the environmental impacts of the detailed input products and activities during nursery production, these studies have estimated carbon sequestration from the atmosphere during the life of the plant, weighted over a 100-year assessment period.

Protocols for plant production in containers are significantly different from fieldproduction systems (Ingram and Hall, 2015a). Nursery production systems for shrubs, trees, perennials, etc. are also markedly different from greenhouse systems used for producing propagative stock (young plants), potted flowering plants, bedding plants, and foliage plants. To date, however, the literature regarding the environmental aspects of greenhouse crop production using LCA procedures is sparse. Thus, our objective in this study was to analyze the environmental impact potentials of greenhouse plant production using young foliage plants grown in the southern Unites States as a case study.

This information should be appealing to consumers who are becoming increasingly aware of the potential environmental impact(s) of the products they purchase, including green industry products and services (Yue et al., 2016). Greenhouse growers also need information about the potential impact of specific production protocols to make informed decisions (Ingram and Hall, 2015b) regarding input use and cultural practice selection. This study should help fill that void.

\section{Materials and Methods}

Two systems (entitled System A and System B) were modeled for a 12-week production system for young foliage plants in 72 -count propagation trays $\left(0.15 \mathrm{~m}^{2}\right)$ to be marketed to greenhouse growers for finishing to a marketable size. The protocols for both model systems were based on interviews with producers in the deep south of the United States and access to their records to determine input products, equipment use, heating and cooling requirements, water use, and labor hours for each operation or cultural practice. The average daily temperature in this region is $21.3{ }^{\circ} \mathrm{C}$. The substrate typically used contains $80 \%$ peat and $20 \%$ 
perlite by volume. The young plants would be transplanted as tissue-cultured microcuttings, misted for 4 weeks and grown an additional 8 weeks before being marketed. Because the modeled facilities were closed systems, the irrigation and misting would result in no runoff from the greenhouses.

In both systems, microcuttings would be misted 60 times per day at $98 \mathrm{~mL} \cdot \mathrm{m}^{-2}$ for 4 weeks which required a $3.73 \mathrm{~kW}$ submersible pump operating $0.05 \mathrm{~h} \cdot \mathrm{d}^{-1}$ per bench. It was assumed that microcuttings would be purchased at $\$ 0.20$ each, their CF would be insignificant, and there would be $10 \%$ shrinkage. The crop would be drenched with a biological fungicide (Bacillus amyloliquefaciens) four times at $0.001 \mathrm{~kg}$ of product per tray and sprayed with an insecticide five times at $0.0004 \mathrm{~kg}$ of product per tray. A sprayer with a 5-kW gasoline engine would be used a total of $0.01 \mathrm{~h} /$ tray for pest management per crop. Trays would be graded and consolidated into full trays at the rate of 60 trays per person per 8-h day. One person would move graded trays 40 at a time on a cart into a delivery truck every $10 \mathrm{~min}$.

Water would be used for evaporative cooling through fan and pad systems operating 9 months per year for an average of 8 $h \cdot d^{-1}$. Based on grower interviews, water use for evaporative cooling was assumed to be 3.4 and $5.2 \mathrm{~L} \cdot \mathrm{m}^{-2} \cdot \mathrm{d}^{-1}$ for System A and $\mathrm{B}$, respectively.
System A and System B differed by greenhouse type, bench size, and arrangement, rainwater capture, and irrigation/fertilization method. System A was modeled as an older, gutter-connected, rounded-arch $5574 \mathrm{~m}^{2}$ greenhouse without a ridge vent, a double layer of polyethylene film on the roof, biwall polycarbonate sidewalls, and a 3-m gutter height. Shadecloth was installed inside the house. The $58-\mathrm{m}^{2}$ benches would be stationary and hold 365 72-cell trays each. Movement of trays from the potting area to the mist benches and from the mist benches to production houses using a manual trolley system would require 0.5 labor hours per 60-tray load.

Irrigation in System A would be provided via overhead spray nozzles applying $757 \mathrm{~L}$ per bench per irrigation. Irrigation would be driven by a $3.73-\mathrm{kW}$ pump drawing water from a well. The fan and pad evaporative cooling system would operate an average of $8 \mathrm{~h} \cdot \mathrm{d}^{-1}$. Fertilization would be provided with each watering with $150 \mathrm{mg} \mathrm{N} / \mathrm{L}$ from a $20 \mathrm{~N}$ $4.3 \mathrm{P}-16.6 \mathrm{~K}$ water-soluble fertilizer. The benches would be irrigated 28 times for $10 \mathrm{~min}$. each for a total of $64.5 \mathrm{~L}$ per tray during the 8 weeks of production. The System A greenhouse would be heated by a natural gas boiler combusting an average of $134 \mathrm{~m}^{3}$ of natural gas per bench per crop. Electricity for the greenhouse and support areas would average $4 \mathrm{kWh}$ per marketable tray, not including electricity for pumping which is accounted for separately. Much of the labor is accounted for in each operation, however, it was assumed that there would be $0.04 \mathrm{~h}$ of unallocated labor per tray in System A.

System B was modeled as a more modern gutter-connected, Dutch-style greenhouse using natural ventilation with roof vents and retractable shade interior to the house using an integrated environmental control system. The roof and sidewalls were covered with bilayer polycarbonate and the gutter height was $3.6 \mathrm{~m}$. The $10,220 \mathrm{~m}^{2}$ greenhouse would be designed with a gutter system to capture rainfall and store it in $1900 \mathrm{~m}^{3}$ tanks.

Sixty-nine trays would be placed on each moveable $10 \mathrm{~m}^{2}$ bench and pushed by hand to the desired location for misting, production, and preparation for shipping. Water captured from the roof would be treated and used in an ebb-flood system contained in the individual moveable tables. It was assumed that $242 \mathrm{~L}$ were required to flood each bench for 26 irrigations and $80 \%$ would be returned to the reservoir/tank. Water in the storage tank and supplemental well water added to the system, would be treated with calcium hypochlorite tablets $(0.057 \mathrm{~kg}$ per bench per crop) to maintain $1 \mathrm{mg} \cdot \mathrm{L}^{-1}$ free chlorine. A $5.60 \mathrm{~kW}$ electric pump would be used to pump irrigation water to the production benches for a total of $0.17 \mathrm{~h}$ per bench per crop. In addition, a 1.49-kW electric pump would

Table 1. Global warming potential (GWP) and variable costs of production components for System A for greenhouse production of young foliage plants in a 72-cell tray in the southern United States.

\begin{tabular}{|c|c|c|c|c|c|c|c|c|c|}
\hline \multirow[b]{2}{*}{ Activity/Components } & \multicolumn{3}{|c|}{ Materials } & \multicolumn{3}{|c|}{ Equipment use } & \multirow{2}{*}{$\frac{\text { Labor }}{\text { Costs }(\$)}$} & \multicolumn{2}{|l|}{ Total } \\
\hline & $\mathrm{kg}$ or unit/tray & $\mathrm{GWP}\left(\mathrm{kg} \mathrm{CO}_{2} \mathrm{e}\right)$ & Costs $(\$)$ & $\mathrm{h} /$ tray & $\mathrm{GWP}\left(\mathrm{kg} \mathrm{CO}_{2} \mathrm{e}\right)$ & Costs $(\$)$ & & $\overline{\mathrm{GWP}\left(\mathrm{kg} \mathrm{CO}_{2} \mathrm{e}\right)}$ & Costs $(\$)$ \\
\hline Microcutting and $t$ ransplanting & 72.0000 & 0.0000 & 16.000 & 0.0000 & 0.0000 & 0.000 & 3.223 & 0.0000 & 19.223 \\
\hline Misting & 0.0000 & 0.0000 & 0.000 & 0.0021 & 0.0054 & 0.010 & 0.010 & 0.0054 & 0.020 \\
\hline Irrigation/water management & 0.0000 & 0.0000 & 0.000 & 0.0265 & 0.0181 & 0.019 & 0.010 & 0.0181 & 0.029 \\
\hline Fertilization & 0.0484 & 0.1505 & 0.055 & 0.0000 & 0.0000 & 0.000 & 0.000 & 0.1505 & 0.055 \\
\hline Heating (natural gas) & 0.0000 & 0.0000 & 0.000 & 0.4354 & 1.0448 & 0.137 & 0.000 & 1.0448 & 0.137 \\
\hline Electricity $(\mathrm{kWh})$ & 0.0000 & 0.0000 & 0.000 & 4.0307 & 2.7570 & 0.368 & 0.000 & 2.7570 & 0.368 \\
\hline Unallocated grower/labor & 0.0000 & 0.0000 & 0.000 & 0.0000 & 0.0000 & 0.000 & 0.509 & 0.0000 & 0.509 \\
\hline Totals per tray & 72.1436 & 0.3990 & 19.114 & 4.4972 & 3.8256 & 0.548 & 5.080 & 4.2246 & 25.251 \\
\hline
\end{tabular}

Table 2. Global warming potential (GWP) and variable costs of production components for System B for greenhouse production of young foliage plants in a 72-cell tray in the southern United States.

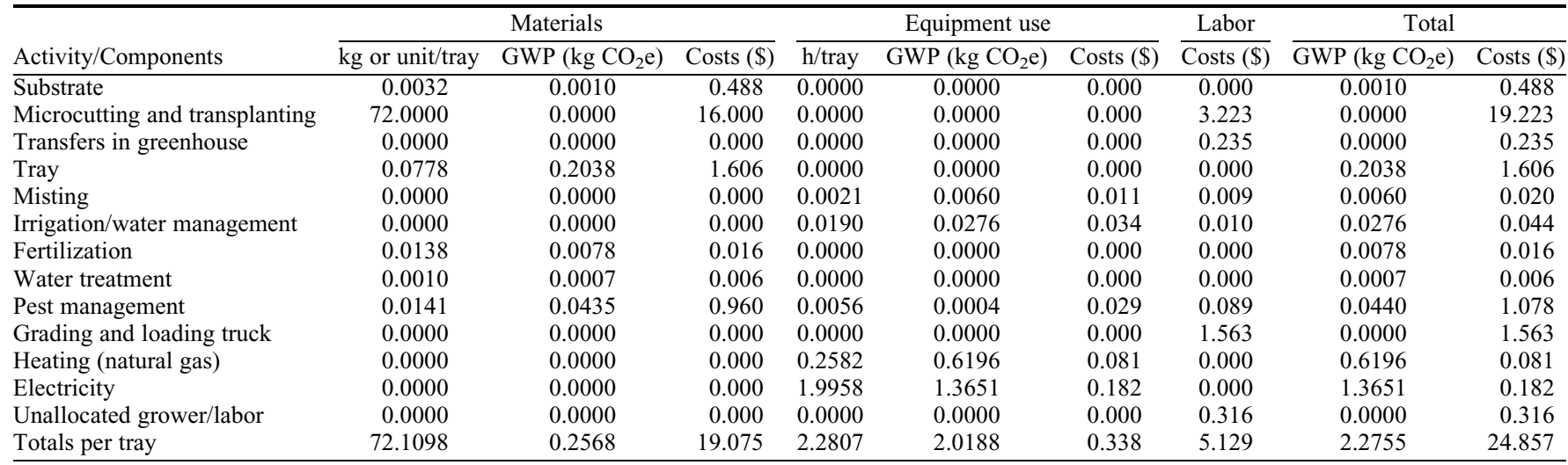


run $12 \mathrm{~h}$ per day or $0.76 \mathrm{~h}$ per bench for the 8 weeks to push returning water through a filter system and circulate water in the reservoir where the chlorine would be added. Fertilizer (20N-4.3P-16.6K) would be added to the water reservoir to maintain $130 \mathrm{mg} \mathrm{N} / \mathrm{L}$.

Recommended fertilizer concentration for ebb-flood systems is lower than for plants receiving overhead irrigation due to differential leaching and thus salt accumulation (Liu et al., 2012). Greenhouses in System B would be heated by two natural gas boilers, combusting an average of $15.3 \mathrm{~m}^{3}$ of natural gas per bench per crop. Electricity for the greenhouse and support areas would average $0.87 \mathrm{kWh}$ per marketable tray, not including electricity for pumping water which was accounted for separately. Much of the labor was accounted for in each operation, however, it was assumed that there would be $0.025 \mathrm{~h}$ of unallocated labor per tray in System B.

Inventory analysis and data collection. All input products, equipment use and other activities were recorded using life cycle inventory procedures for a functional unit of one 72-cell tray of foliage plants. LCA protocols were applied to the inventory following international standards, including the International Organization for Standardization (2006) (Geneva, Switzerland) and PAS 2050 guidelines by BSI British Standards (2011). GHG were determined for each input and activity, converted to kilograms $\mathrm{CO}_{2} \mathrm{e}$ per functional unit and summed. Emissions from the manufacturing of capital goods, such as buildings and machinery, were not included in this study as per PAS 2050, Section 6.4.4.

GWP of 9.7, 1.0, and $0.7 \mathrm{~kg} \mathrm{CO}_{2} \mathrm{e} / \mathrm{kg}$ for $\mathrm{N}$ from $\mathrm{NH}_{4} \mathrm{NO}_{3}, \mathrm{P}_{2} \mathrm{O}_{5}$, and $\mathrm{K}_{2} \mathrm{O}$ fertilizers, respectively, were assumed as previously published (Snyder et al., 2009; Wang, 2007). The U.S. life cycle inventory (USLCI) database (U.S. Dept. Energy, 2016) and SimaPro (Pre' North America, Inc., Washington, DC) were used to calculate a GWP of input products, including manufacturing processes and transportation. It was assumed that $\mathrm{N}$ was from $\mathrm{NH}_{4} \mathrm{NO}_{3}$. Although probably not totally representative of organic substrates, a $1 \%$ loss of applied $\mathrm{N}$ as $\mathrm{N}_{2} \mathrm{O}$ was assumed based on research with field soils and resulted in an estimated GWP of $4.65 \mathrm{~kg} \mathrm{CO}_{2} \mathrm{e} / \mathrm{kg}$ of $\mathrm{N}$ applied (Intergovernmental Panel on Climate Change (IPCC), 2006; Snyder et al., 2009; West and Marland, 2003). The GWP of natural gas combusted in an industrial boiler and the GWP of electricity in the region were set as $2.40 \mathrm{~kg} \mathrm{CO} / \mathrm{m}^{3}$ and 0.684 $\mathrm{kg} \mathrm{CO}_{2} \mathrm{e} / \mathrm{kWh}$, respectively, from USLCI data through SimaPro. Electricity for individual activities was calculated, and remaining electricity use was determined by consulting grower records for overall use and expressed as overhead electricity.

The substrate consisted of $80 \%$ peat and $20 \%$ perlite by volume considering a $5 \%$ shrinkage during mixing. GWP was calculated to be $0.317 \mathrm{~kg} \mathrm{CO}_{2} \mathrm{e} / \mathrm{kg}$, of which 0.100 $\mathrm{kg} \mathrm{CO}_{2} \mathrm{e}$ was from peat $(0.945 \mathrm{~kg})$ and 0.217 $\mathrm{kg} \mathrm{CO} 2 \mathrm{e}$ was from perlite $(0.121 \mathrm{~kg})$, which included mixing and transportation. The GWP of peat was based on a German model adjusted for U.S. energy by Ecoinvent database (Ecoinvent Centre, 2015) accessed through SimaPro and the GWP of perlite was obtained from the USLCI database. A GWP of the trays manufactured from polystyrene using a blow-mold technology was calculated to be $2.620 \mathrm{~kg} \mathrm{CO} \mathrm{CO}_{2} \mathrm{e} / \mathrm{kg}$, assuming a transported distance of $200 \mathrm{~km}$ and landfill disposal of used material. The average $\mathrm{CO}_{2} \mathrm{e}$ emission for a range of fungicides $(12.50 \mathrm{~kg}$ $\left.\mathrm{CO}_{2} \mathrm{e} / \mathrm{kg}\right)$ and insecticides $(18.69 \mathrm{~kg} \mathrm{CO} 2 \mathrm{e} / \mathrm{kg})$ were calculated from data presented by Lal
(2004). Calcium hypochlorite tablets were the source for chlorine with a GWP of 1.09 $\mathrm{kg} \mathrm{CO}{ }_{2} \mathrm{e} / \mathrm{kg}$ (U.S. Dept. Energy, 2016).

Costs of inputs, equipment use, and labor were determined for the model systems based on the life cycle inventory. Labor requirements for operating equipment were calculated as 1.25 times the equipment operation hours to account for preparation and clean-up time. Labor contributes significantly to costs but does not contribute directly to the GWP of the product. The Adverse Effect Wage Rate as determined by the U.S. Dept. of Labor (2016) was used to set the hourly wage

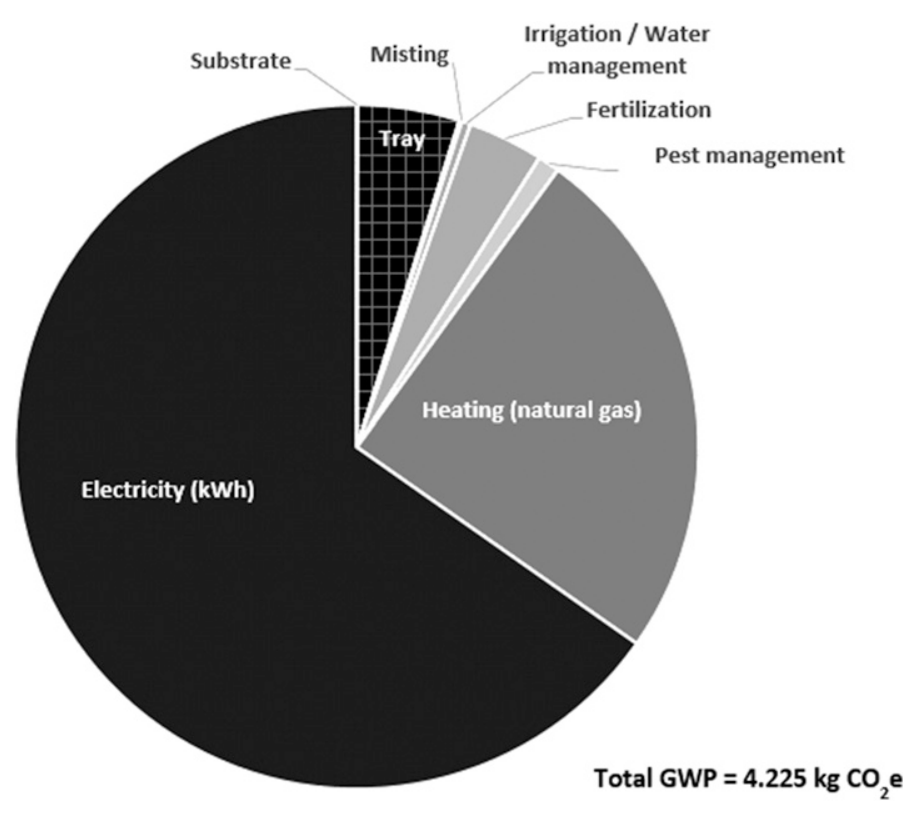

Fig. 1. Global warming potential for production components and activities for a 72-count tray of young foliage plants modeled as a 12 -week crop in a gutter-connected, rounded-arch greenhouse without a ridge vent, and covered with double-layer polyethylene and having stationary benches (System A).

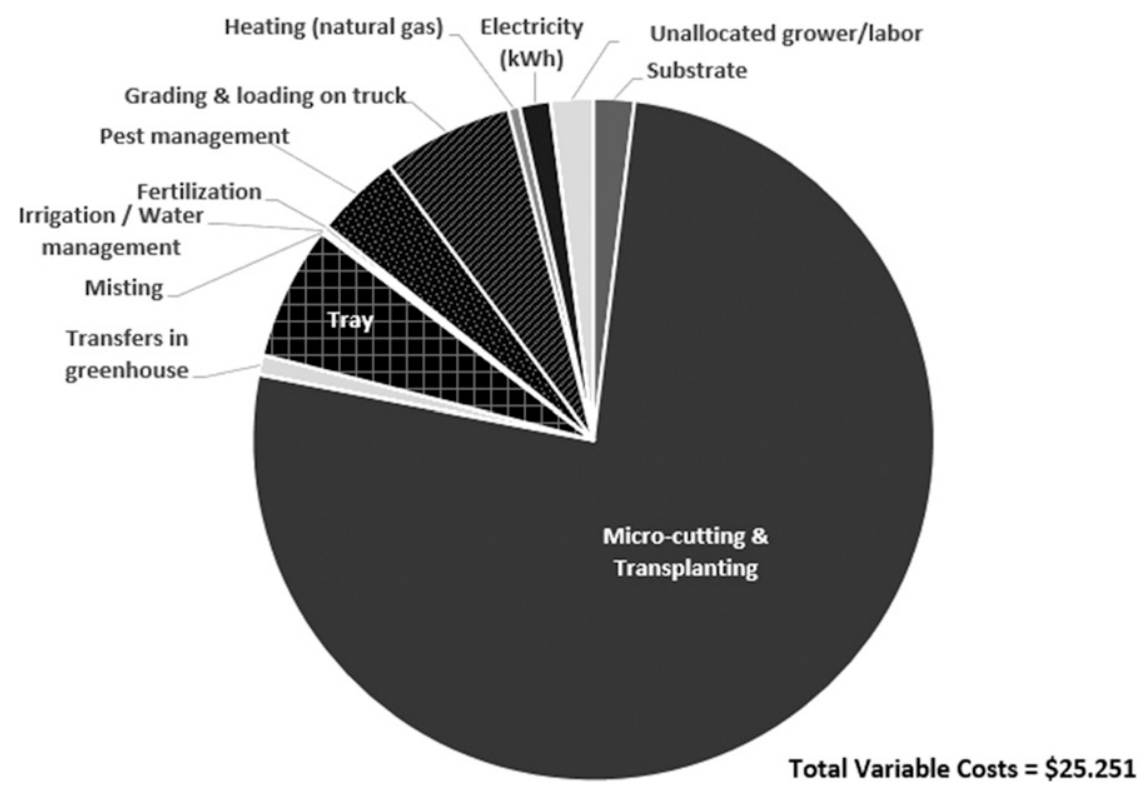

Fig. 2. Variable costs for production components and activities for a 72-count tray of young foliage plants modeled as a 12 -week crop in a gutter-connected, rounded-arch greenhouse without a ridge vent, and covered with double-layer polyethylene and having stationary benches (System A). 
rate of $\$ 12.69$. This represents the wage level that must be offered and paid to migrant workers by agricultural employers of nonimmigrant $\mathrm{H}-2 \mathrm{~A}$ agricultural workers. This rate was used because it acts as a price floor for labor engaged in agricultural or horticultural enterprises. Equipment costs per hour were representative of those reported in regional enterprise budgets for horticultural crops. Natural gas and electricity prices were established as $\$ 0.386 / \mathrm{m}^{3}$ and $\$ 0.091 / \mathrm{kWh}$ through grower interviews.

\section{Results and Discussion}

The GWP due to the GHG from production, distribution, and use of input products, use of equipment and environmental control, and other activities for production of young foliage plants in 72-count trays were calculated to be 4.225 and $2.276 \mathrm{~kg} \mathrm{CO}_{2} \mathrm{e}$ for Systems A and B, respectively (Tables 1 and $2)$. Total variable costs per tray of these systems were calculated as \$25.251 and $\$ 24.857$, respectively.

Electricity and natural gas use were by far the greatest contributors to GWP of the finished tray of young foliage plants in both systems, but neither was a major contributor to the variable cost (Figs. 1-4). The primary cost item for both System A and B was the microcutting from tissue culture and the cost of transplanting those into the 72-count trays (\$19.223). However, the contribution of the microcutting to GWP was insignificant. This differs from field production of trees and shrubs where the items contributing to GWP were also primary contributors to the variable costs, principally due to equipment use on individual plants (Hall and Ingram, 2014, 2015; Ingram, 2013; Ingram and Hall, 2013, 2014a, 2014b).

The GWP of most inputs and processes were similar between the two systems. Generally, the more modern greenhouse in System B could be characterized as being more efficient in terms of space utilization for production, heating and cooling, fertilization, and water use. The substrate, microcutting, misting, and labor-intensive processes such as transplanting, transferring within the greenhouse, grading, order pulling, and loading each contributed no more than $0.001 \mathrm{~kg} \mathrm{CO}_{2} \mathrm{e}$ to the GWP of System A or B (Tables 1 and 2). The 72-count tray contributed $0.204 \mathrm{~kg} \mathrm{CO}_{2} \mathrm{e}$ which was only $5 \%$ and $9 \%$ of the total GWP for Systems A and $\mathrm{B}$, respectively.

The $46 \%$ lower GWP for System B compared with System A was due primarily to differences in electricity, heating, and fertilization (Figs. 1 and 3). For System A, electricity and heating contributed 2.757 and $1.045 \mathrm{~kg} \mathrm{CO} \mathrm{CO}_{2} \mathrm{e}$ whereas they contributed 1.365 and $0.620 \mathrm{~kg} \mathrm{CO}_{2} \mathrm{e}$ for System $\mathrm{B}$, respectively (Tables 1 and 2). Electricity and heating with natural gas contributed $\$ 0.368$ and \$0.137 to the costs in System A whereas they contributed $\$ 0.182$ and $\$ 0.081$ for System B, respectively. Electricity and natural gas accounted for $90 \%$ of the GWP of

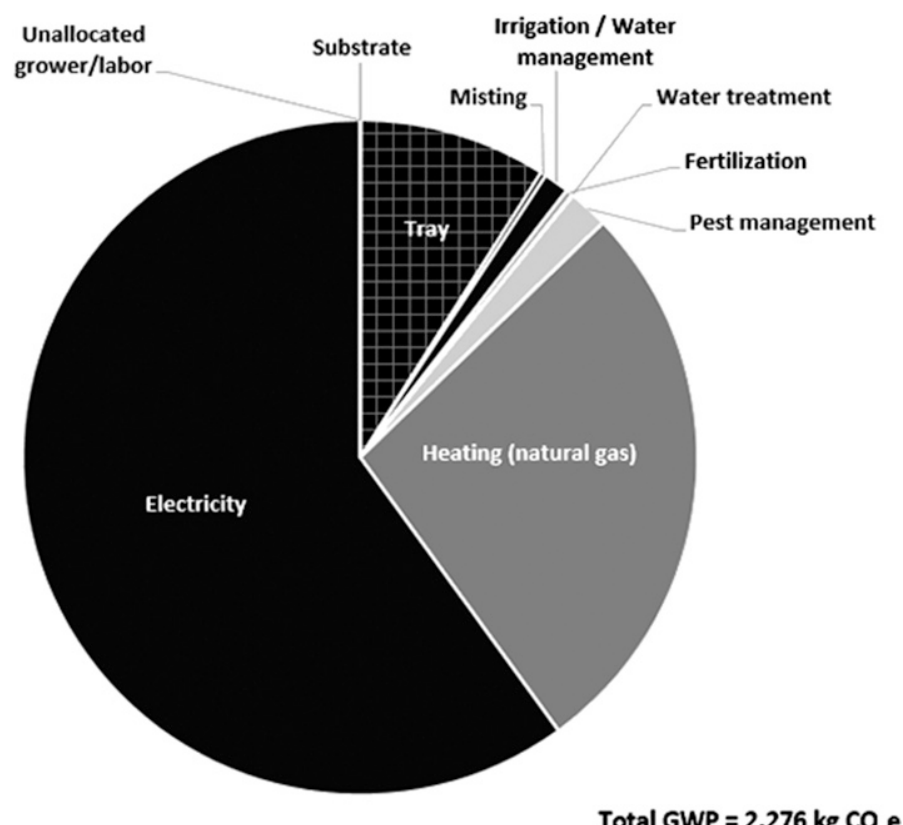

Total GWP $=2.276 \mathrm{~kg} \mathrm{CO} \mathrm{C}_{2}$

Fig. 3. Global warming potential for production components and activities for a 72-count tray of young foliage plants modeled as a 12-week crop in a more modern gutter-connected, Dutch-style greenhouse using natural ventilation and moveable ebb-flood production tables (System B).

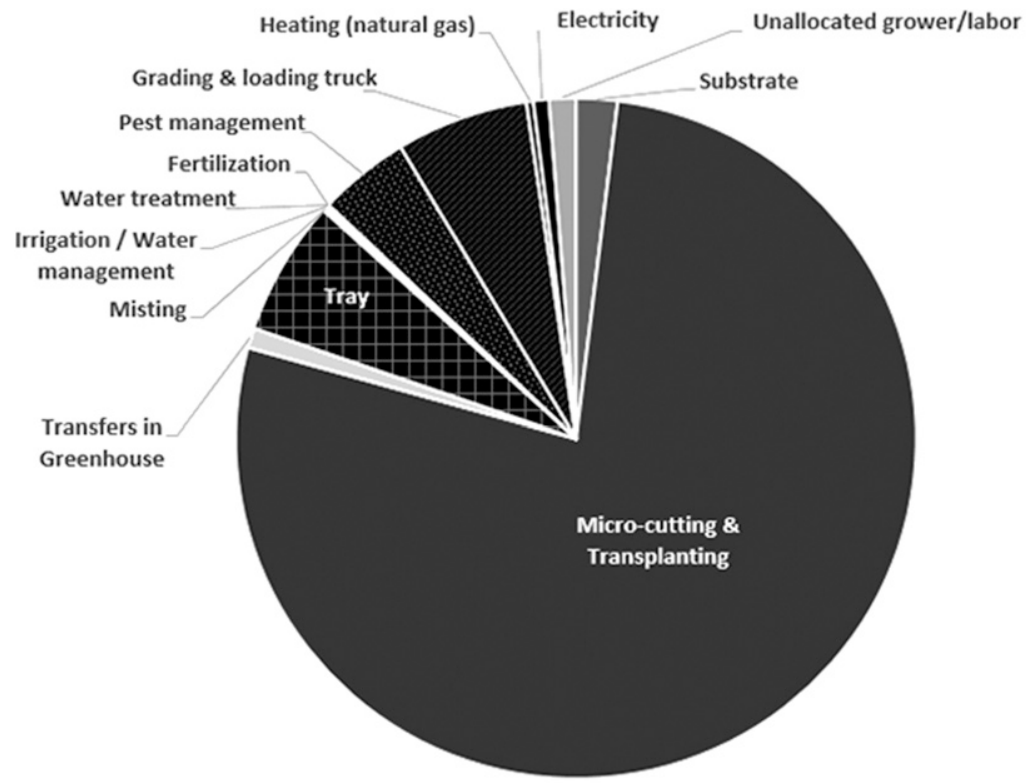

Total Variable Costs $=\$ 24.857$

Fig. 4. Variable costs for production components and activities for a 72-count tray of young foliage plants modeled as a 12-week crop in a more modern gutter-connected, Dutch-style greenhouse using natural ventilation, and moveable ebb-flood production tables (System B).

the tray of young plants in System A and $87 \%$ in System B and $1.9 \%$ of the variable costs in both systems (Figs. 1-4). The greater potential for natural ventilation in System B would be expected to result in decreased electricity use for exhaust fans and evaporative cooling than System A. The polycarbonate covering in System B would also result in less heat loss than the doublelayer polyethylene covering in System A (U.S. Dept. of Agriculture, Agricultural
Research Service, 2017). System B also has a slightly lower space use (4.5 trays $/ \mathrm{m}^{2}$; benches occupy $72 \%$ of greenhouse area) than System B because of the moveable benches (5.7 trays $/ \mathrm{m}^{2}$; benches occupy $86 \%$ of greenhouse area) and the difference in space use efficiency would impact the heating and cooling requirements for a tray. This would potentially impact the allocation of overhead costs on an area basis although this LCA did not consider differences in 
capital investments, nor the overhead costs associated with them.

Fertilization accounted for 0.150 and $0.008 \mathrm{~kg} \mathrm{CO}_{2} \mathrm{e}$ of the GWP and $\$ 0.055$ and $\$ 0.016$ of variable costs for Systems A and $\mathrm{B}$, respectively (Tables 1 and 2). Irrigation, water management, and water treatment together contributed 0.018 and 0.028 $\mathrm{kg} \mathrm{CO} 2$ e to the GWP and \$0.029 and \$0.044 to the cost of the product in Systems A and $\mathrm{B}$, respectively. Less fertilizer was required for the subsurface irrigation method in System B than the overhead sprinkler irrigation in System A because of the lack of leaching and salt accumulation in subsurface irrigation systems (Liu et al., 2012; IGE Staff, 2016). Also, recycling of the water also recycles nutrients but adds GWP and cost for pumping, filtering, and treating recycled water. Electrical pumps for irrigation, water management, and water treatment added $0.018 \mathrm{~kg} \mathrm{CO}_{2} \mathrm{e}$ to the GWP of the product and $\$ 0.029$ to variable costs in System A compared with $0.028 \mathrm{~kg} \mathrm{CO}_{2} \mathrm{e}$ and $\$ 0.034$ for System B. Misting during the rooting stage of the micro cuttings only contributed 0.005 and $0.006 \mathrm{~kg} \mathrm{CO}_{2} \mathrm{e}$ and $\$ 0.020$ and $\$ 0.020$ to variable costs for Systems A and B, respectively. The total GWP of water management, including pumping water from the source, movement of water within the nursery, misting, and irrigation for Systems $\mathrm{A}$ and $\mathrm{B}$ were calculated as 0.024 and $0.034 \mathrm{~kg} \mathrm{CO}_{2} \mathrm{e}$, respectively.

Water use also differed between the two systems. Although water use for misting was similar between the systems at $\approx 25 \mathrm{~L}$ per tray, production water use was greater in System A than in System B. This would be expected given the recycling of water in the ebb-flood system of System B. About 64 $\mathrm{L}$ of water per tray is applied in irrigation for System A while only $21 \mathrm{~L}$ are added to the system per tray in System B model. Interestingly, the water requirements for evaporative cooling were greater than for irrigation in these models. Water use for evaporative cooling was estimated at 53 and $64 \mathrm{~L}$ per tray in Systems A and B, respectively.

These results point to the need for growers to consider the differences in efficiencies and their resulting impact on $\mathrm{CF}$ and costs (both variable and overhead) when evaluating structures for greenhouse construction. Historically, sunk costs (those already made) have had too much influence on grower decision-making regarding potential investments, particularly regarding structures (Hall, 2010). When making investment decisions as to which system to implement, a net present value analysis of future or prospective costs would be an appropriate tool to use. Although outside the scope of this analysis, we hypothesize that given the variable cost structure found in this study, System B would more likely lead to greater cost savings and/or increases in revenue for the greenhouse operation and would thus be the more favorable option.
Interestingly, the use of System B also leads to a smaller carbon (and potentially water) footprint.

As far as the impacts of these results on consumers, previous studies have shown a segment of consumers have a willingness to pay more for plants that are grown using environmental-friendly techniques. Yue et al. (2016) found that, compared with conventional plants, environmental-minded consumers (about 14\% of the respondents surveyed) were willing to pay $\$ 0.18$ more for bedding plants grown in a "sustainable" method, \$0.46 more for plants grown with energy-saving methods, and $\$ 0.22$ more for plants grown with water-saving methods. Compared with plants in conventional plastic containers, they were willing to pay $\$ 0.37$ more for plants in compostable containers, $\$ 0.43$ for plants in plantable containers, and $\$ 0.14$ more for plants in recyclable containers. They liked local plants and plants grown in the United States and were willing to pay $\$ 1.99$ more for locally-grown plants and $\$ 1.73$ more for domestically grown plants compared with their imported counterparts. Because the results of this study indicate that foliage plants grown using System B are more energy- and water-saving, one might surmise that this would weigh favorably for this segment of consumers.

Unlike woody landscape plants, however, young (and even mature) foliage plants do not contribute to long-term carbon sequestration due to the lack of wood production and their shorter life expectancy. However, in addition to their esthetic value, they do provide selected ecosystem services through improved air quality (including removal of volatile organic compounds), enhanced biodiversity, and storm water management. Recent research also points to the numerous health and well-being benefits of foliage plants including increased productivity, higher levels of employee satisfaction, reduced absenteeism, reduced stress, faster attention deficit recovery, and other biophilic design benefits (Hall and Dickson, 2011). These benefits should appeal to the aforementioned environmental-conscious consumers, as well as those who value health and well-being.

\section{Literature Cited}

Boston Consulting Group. 2009. The business of sustainability: Imperatives, advantages, and actions. 31 Mar. 2017. <bcg.com>.

BSI British Standards. 2011. Specification for the assessment of the life cycle greenhouse gas emissions of goods and services. BSI British Standards (Publicly Available Specification) PAS 2050:2011. ISBN 9780580713828. $45 \mathrm{p}$.

Ecoinvent Centre. 2015. Ecoinvent 3.0. Competence Centre of the Swiss Federal Institute of Technology, Zurich, Switzerland. 17 July 2015. <http://www.ecoinvent.org/database/>.

Hall, C.R. 2010. Making cents of green industry economics. HortTechnology 20:832-835.

Hall, C.R. and M.W. Dickson. 2011. Economic, environmental, and health/well-being benefits associated with green industry products and services: A review. J. Environ. Hort. 29(2): 96-103.

Hall, C.R. and D.L. Ingram. 2014. Production costs of field-grown Cercis canadensis L. 'Forest Pansy' identified during life cycle assessment analysis. HortScience 49:1-6.

Hall, C.R. and D.L. Ingram. 2015. Carbon footprint and production costs associated with varying the intensity of production practices during field-grown shrub production. HortScience 50:402-407.

IGE Staff. 2016. Tips for growing on ebb and flow benches. Innovative Grower Equipment, Inc. Blog. 15 Apr. 2017. <https://www. innovativegrowersequipment.com/single-post/ 2016/06/13/tips-for-growing-on-ebb-and-flowbenches $>$.

Ingram, D.L. 2012. Life cycle assessment of a field-grown red maple tree to estimate its carbon footprint components. Intl. J. Life Cycle Assess. 17:453-462.

Ingram, D.L. 2013. Life cycle assessment to study the carbon footprint of system components for Colorado blue spruce field production and landscape use. J. Amer. Soc. Hort. Sci. 138:3-11.

Ingram, D.L. and C.R. Hall. 2013. Carbon footprint and related production costs of system components of a field-grown Cercis canadensis L. 'Forest Pansy' using life cycle assessment. J. Environ. Hort. 31(3):169-176.

Ingram, D.L. and C.R. Hall. 2014a. Carbon footprint and related production costs of system components for a field-grown Viburnum $\times j u d d i$ using life cycle assessment. J. Environ. Hort. 32:175-181.

Ingram, D.L. and C.R. Hall. 2014b. Life cycle assessment used to determine the potential environment impact factors and water footprint of field-grown tree production inputs and processes. J. Amer. Soc. Hort. Sci. 140:102107.

Ingram, D.L. and C.R. Hall. 2015a. Carbon footprint and related production costs of pot-in-pot system components for red maple using life cycle assessment. J. Environ. Hort. 33(3):103109.

Ingram, D.L. and C.R. Hall. 2015b. Using life cycle assessment (LCA) to determine the carbon footprint of trees during production, distribution and useful life as the basis for market differentiation. Acta Hort. 1090:35-38. (Proc. First Intl. Symp. Hort. Economics, Mktg. Consumer Res.).

Ingram, D.L., C.R. Hall, and J. Knight. 2016. Carbon footprint and variable costs of production components for a container-grown evergreen shrub using life cycle assessment: An east coast U.S. model. HortScience 51: 989-994.

Intergovernmental Panel on Climate Change (IPCC). 2006. Guidelines for national greenhouse gas inventories. Volume 4: Agriculture, forestry and other land use. Chapter 11: $\mathrm{N}_{2} \mathrm{O}$ emissions from managed soils, and $\mathrm{CO}_{2}$ emissions from lime and urea application. 13 July 2017. $<$ http://www.ipcc-nggip.iges.or.jp/public/2006gl/ vol4.html $>$.

International Organization for Standardization (ISO). 2006. Life cycle assessment, requirements and guidelines. ISO Rule 14044:2006. Intl. Organization for Standardization, Geneva, Switzerland. 59 p.

Kendall, A. and E.G. McPherson. 2012. A life cycle greenhouse gas inventory of a tree production system. Intl. J. Life Cycle Assess. 17(4):444-452. 
Lal, R. 2004. Carbon emissions from farm operations. Environ. Intl. 30:981-990.

Liu, J., W.R. Leatherwood, and N.S. Mattson. 2012. Irrigation method and fertilization concentration differentially alter growth of vegetable transplants. HortTechnology 22: 56-63.

Rankin, A., A. Gray, M. Boehlje, and C. Alexander. 2011. Sustainability strategies in U.S. agribusiness: Understanding key drivers, objectives, and actions. Intl. Food Agribus. Mgt. Rev. 14(4): $1-20$.

Snyder, C.S., T.W. Bruulsema, T.L. Jensen, and P.E. Fixen. 2009. Review of greenhouse gas emissions from crop production systems and fertilizer management effect. Agr. Ecosyst. Environ. 133:247-266.

Southern Nursery Association. 2013. Best management practices: Guide for producing nursery crops. 3rd ed. SNA, Acworth, GA.

U.S. Dept. of Agriculture, Agricultural Research Service. 2017. Virtual Grower 3 model. 14 June 2017. <http://ars.usda.gov/Research/docs.htm? docid $=22087>$.

U.S. Dept. Energy. 2016. U.S. Life-cycle inventory database. National Renewable Energy Lab (NREL). 17 Apr. 2017. <https:// www.lcacommons.gov/nrel/search>.
U.S. Dept. of Labor. 2016. Wages in agriculture. 13 Nov. 2016. <https://www.foreignlaborcert. doleta.gov/adverse.cfm>.

Wang, M.Q. 2007. GREET 1.8a spreadsheet model 13 Nov. 2015. <http://www.transportation.anl. gov/modeling_simulation/index.html $>$.

West, T.O. and G. Marland. 2003. Net carbon flux from agriculture: Carbon emissions, carbon sequestration, crop yield, and land-use change. Biogeochemistry 63(1):73-83.

Yue, C., B. Campbell, C. Hall, B. Behe, J. Dennis, and H. Khachatryan. 2016. Consumer preference for sustainable attributes in plants: Evidence from experimental auctions. Agribusiness 32(2):222-235. 